This article was downloaded by: [New York University]

On: 08 May 2015, At: 20:08

Publisher: Routledge

Informa Ltd Registered in England and Wales Registered Number: 1072954

Registered office: Mortimer House, 37-41 Mortimer Street, London W1T

3J H, UK

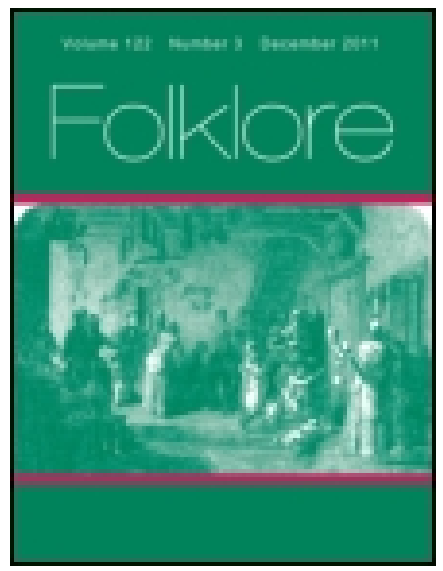

\title{
Folklore
}

Publication details, including instructions for authors and subscription information:

http:// www. tandfonline.com/loi/ rfol20

\section{Notes on Irish Folklore from Connaught, Collected Chiefly in North Donegal}

J. Cooke

Published online: 14 Feb 2012.

To cite this article: J . Cooke (1896) Notes on Irish Folklore from

Connaught, Collected Chiefly in North Donegal, Folklore, 7:3, 299-301, DOI: 10.1080/ 0015587X. 1896.9720370

To link to this article: http:// dx. doi.org/ 10.1080/0015587X.1896.9720370

\section{PLEASE SCROLL DOWN FOR ARTICLE}

Taylor \& Francis makes every effort to ensure the accuracy of all the information (the "Content") contained in the publications on our platform. However, Taylor \& Francis, our agents, and our licensors make no representations or warranties whatsoever as to the accuracy, completeness, or suitability for any purpose of the Content. Any opinions and views expressed in this publication are the opinions and views of the authors, and are not the views of or endorsed by Taylor \& Francis. The accuracy of the Content should not be relied upon and should be independently verified with primary sources of information. Taylor and Francis shall not be liable for any losses, actions, claims, proceedings, demands, costs, expenses, damages, and other liabilities whatsoever or howsoever caused arising directly or indirectly in connection with, in relation to or arising out of the use of the Content.

This article may be used for research, teaching, and private study purposes. Any substantial or systematic reproduction, redistribution, reselling, loan, sub-licensing, systematic supply, or distribution in any form to anyone is 
expressly forbidden. Terms $\&$ Conditions of access and use can be found at http://www.tandfonline.com/page/terms-and-conditions 
ened by disease" take the second place; the chief service required was hanging the bodies of stags upon a particular tree in Exmoor Forest.

One step further back we find the grove of Upsala; and $\Lambda$ dam of Bremen tells us: "The grove itself is thought so sacred that single trecs in it are accounted a kind of gods, to the extent of recciving sacrifices of victims. There hang the bodies of dogs and men alike to the number, as some Christians have assured me, of screnty-two together."

In Folklore, vol. iv. p. 5, Mr. Gomme has alluded to this practice and given some instances of similar survivals; but I venture to think that an instance so late as three years ago is worthy of being chronicled. The skeleton is still to be seen in the tree.

T. IV. I. HIGGENS.

\section{Notes on Irisil Folklore from Connaugit, collected chiefly in Norti Donegal.}

To keep fairies from a house.-The broom is placed behind the door in its own place. The fire raked (covered with ashes). The water with which feet were washed thrown on the dunghill.

Curcs.-To cure falling sickness, breathe heavily into the ear three times, saying: "Come out, thou unclean spirit, and enter no more into him."

To cure warts, stick a pointed rod through a snail in shell and let threc drops fall on the wart, place the snail in the thatch of the housc, and as it rots the wart disappears. Also straws taken from cach of the four corners of the house and one from over the doorway to be placed at the nearest cross-roads.

$\Lambda$ woman enceinte sceing a hare or rabbit tears a bit off her chemise and throws it away.

To cure a whitlow or stye, point nine gooseberry thorns in the name of the Trinity and throw a tenth away.

If ten pieces of old iron be taken and placed over a swelling or lump, and the last thrown away, a cure will be effected.

Also anoint with fasting spittle in the morning in the name of the Trinity.

If a person meets a man or woman first on the road with red hair or white, he should turn back, it is unlucky. 
When a will-o'-the-wisp is seen, if the coat is turned inside out and put on again it will disappear and the whereabouts be ascertained.

$A$ child "in the fairies" if washed with water in which fox-glove is steeped the possession is broken. Such a child in modern times was put out on a shovel on the dunghill. $\Lambda$ child I rescued and put in hospital some three years ago, was taken home by her parents believing it was "in the fairies," and it died. No proceedings could be taken in the case, it was so delicate, and proof of neglect was difficult. But the facts are as I state.

In the Aran Islands in case of very difficult childbirth, nine articles of the husband are taken and put in three groups on the bed in the name of the several persons of the Trinity, to insure a safe delivery.

Hallow Eve practices. - $A$ girl washes her chemise against a running stream and says her prayers. She puts the garment at the fire, and the person who is to be her husband comes and turns it.

To run round a hay-stack three times and plunge a black. handled knife into it in the name of the devil. The person who takes it out will marry the other.

Steal a salt herring, roast it without washing, eat it in threc mouthfuls, bones and all, and the person will dream of the one he or she will marry.

The yarrow plant to be taken up by the root with a black. handled knife, placed in left-foot stocking, tied with right-foot garter, placed under the pillow, and the girl will dream of hor future husband.

The same done with first bit, middle bit, and last bit of supper.

$\Lambda$ hen's first egg boiled hard, eaten in three bites, without salt, and the person will dream of the one he or she is to marry.

Another with the egg is to take it with three-cornered handkerchief from the nest, roast it, and eat shell and all, without once touching it with hand.

To go round a looking-glass three times and stick new pins into an apple in the name of the devil, and the person he or she is to marry will appear. Stories of denth from horrible apparitions are told of this and similar practices.

$\Lambda$ nother custom with the glass is to comb the hair in the name of the Trinity. 
$\Lambda$ handful of new wheat to be taken to a stream, part thrown in against the current and the rest caten, the future husband will come and take hold of the girl to prevent her falling in.

66, MLrehampton Road, Dublin.

J. COOKE.

\section{The Ploughman and tile Fairies.}

There was once a poor labourer who had a large family to support, and at that time food was dear. One day he remarked to his wife, "I wish a nice kind of fairy would think of us. My master says I must go and plough the eleven-acre field on Monday morning; that will bring in something, anyhow." On the Monday following he started ploughing and found a bright new shilling at the foot of the plough. He put it into his pockct and prayed for more. The second morning when he got to the ficld he found two bright new shillings lying on the freshly-turned furrows of the day before. These he pocketcd too. On the third morning there were three new shillings. Delighted, he pocketed them and prayed for more. On his return home he said to his wife, "I don't know when I shall finish this ficld, but I sha'n't hurry over it. The longer I am about it the better for me." To that she replied, "All right, Joc I" On the fourth morning there were four new shillings. So it went on, a fresh shilling boing added each day, until he had collected quite a pilc of brand new shillings. Then he thought to himself, "I cannot kcep this money from my wife any longer, as the poor children are in want." So he gave his wife ten new shillings. She looked at them and asked immediately: "Joe, where ever did you get all these shillings, and new too?" "Never you mind as lontg as you've got it," replied the labourer. She took the money and went to the village to shop, buying bread, butter, tea, and sugar, and some other things. Joe kept giving her more shillings, until one day she asked suspiciously: "Has your master paid you your week's wages yet?" "No, no," he said, "he hasn't got no change, but I can give you some more shillings." $\Lambda$ nd he did. She looked at them doubtfully and said, "Well, Joe I all bright shillings again. They look as if they had only just been madc. 